\title{
Child Care Center Directors' Opinions, Overuse of Antibiotics, and Social Policy
}

\author{
Jonathan B. Kotch, MD, MPH; David J. Weber, MD, MPH
}

(See the article by M'ikanatha et al, on pages $408-411$.)

The Concise Communication by M'ikanatha et $\mathrm{al}^{1}$ in this issue of Infection Control and Hospital Epidemiology, "Child Care Center Exclusion Policies and Directors' Opinions on the Use of Antibiotics," is a useful window into child care policies and child care directors' opinions about the use of antibiotics in child care. Given our knowledge that infectious disease is more common among children in child care than among children reared at home, ${ }^{2}$ it not surprising that directors, not to mention parents, are concerned. For parents, a child's illness often means medical expenses, a day (or more) of lost wages, or the extra expense of hiring an in-home caregiver or placing their child in a facility specializing in the care of children with acute, self-limited illness or injury. For directors, although they generally do not refund tuition for a child's sick days, a reputation for unusually high illness rates or even strict infection control policies could mean the loss of potential customers. These are powerful incentives for both directors and parents to try to reduce the impact of infectious disease on the individual child and on the child care center.

Americans are hooked on medication, and antibiotics are a case in point. There are communicable diseases that occur among children in child care for which requiring antibiotic treatment is appropriate. For example, children with impetigo or streptococcal pharyngitis should be excluded until 24 hours after initiation of antibiotic treatment. ${ }^{3}$ It is understandable that parents and providers would extrapolate from this example to other infectious diseases. Yet most infections acquired in child care are due to viruses, ${ }^{4,5}$ making antibiotic treatment worse than futile, adding both to medical care costs and the real risk of selection of antibiotic-resistant organisms. The American Academy of Pediatrics (AAP) explicitly states that the following conditions do not necessitate exclusion: nonpustular rash without fever and behavioral change, conjunctivitis without fever and behavioral change, and carriage of methicillin-resistant Staphylococcus aureus. Furthermore, they do not include viral upper respiratory infections in their list of exclusions.

The best way to deal with infectious disease in child care is to prevent it with immunization. A good example of a recently introduced vaccine that has resulted in measurable reduction in illness rates among children in out-of-home child care is varicella, ${ }^{6}$ for which exposure to child care had been a risk. ${ }^{7}$ There is hope that immunization against rotavirus will reduce the risk of child care-acquired diarrhea due to rotavirus, the leading cause of infectious diarrhea in child care. ${ }^{4,8}$ In addition, general practices that have been validated to reduce infection transmission should be used, such as appropriate hand hygiene, proper environmental cleaning/disinfection of diaper-changing surfaces and toys, and safe food preparation. ${ }^{3}$

Nevertheless, increased risk of infectious disease among children in out-of-home child care will continue to be a problem for the foreseeable future. The recommendation made by M'ikanatha et $\mathrm{al}^{1}$ for more education of parents, child care providers, and healthcare providers is very reasonable, and mechanisms exist for offering such education. For example, the joint publication of the AAP, the American Public Health Association, and the National Resource Center for Health and Safety in Child Care (2002) includes recommendations for exclusion from and readmission to child care for children with infectious disease. ${ }^{9}$ The National Training Institute for Child Care Health Consultants (CCHCs) at the University of North Carolina at Chapel Hill (http://nti.unc.edu) has trained more than 400 child health professionals, predominantly nurses, who in turn have trained more than $4,000 \mathrm{CCHCs}$ in 50 states to provide health and safety training, continuing education, consultation, and technical assistance to both centerbased and home-based group child care providers. Similarly, the AAP's Healthy Child Care America Campaign (http:// www.healthychildcare.org/index.html) provides education and support to pediatricians and other healthcare providers

From the Department of Maternal and Child Health, Gillings School of Global Public Health (J.B.K.), and the Department of Medicine (D.J.W.), University of North Carolina at Chapel Hill

Received January 11, 2010; accepted January 13, 2010; electronically published February 22, 2010.

Infect Control Hosp Epidemiol 2010; 31:412-413

(C) 2010 by The Society for Healthcare Epidemiology of America. All rights reserved. 0899-823X/2010/3104-0015\$15.00. DOI: 10.1086/651306 
who work with child care facilities or with the families who use out-of-home child care.

Educational efforts can only go so far in the face of competition from drug company marketing and the compelling social and economic determinants of child care provider and parent behavior. Overprescription of antibiotics among children in child care is a consequence of a social policy that puts the entire cost of child care on the backs of young, working parents. Along with immunization, changes in social policy will be necessary to reduce the demand for a quick fix to exclusion from child care due to infectious disease. Among the most important would be a generous parental leave policy, as is the case in many European countries, ${ }^{10}$ so that parents would not feel compelled to get their sick children back into child care (any child care) as soon as possible to avoid the cost and the stigma of exclusion due to illness. More support for families and for improving the quality and availability of child care would be a public health benefit for the entire community.

Address reprint requests to Jonathan B. Kotch, Department of Maternal and Child Health, Gillings School of Global Public Health, CB\# 7445, Rosenau Hall, University of North Carolina at Chapel Hill, Chapel Hill, NC 27590-7445 (Jonathan_kotch@unc.edu).

\section{REFERENCES}

1. M'ikanatha NM, Gasink LB, Kunselman A, Warren K, Lautenbach E.
Child care center exclusion policies and directors' opinions on the use of antibiotics. Infect Control Hosp Epidemiol 2010;31(4):408-411 (in this issue).

2. Bell DM, Gleiber DW, Mercer AA, et al. Illness associated with child day care: a study of incidence and cost. Am J Public Health 1989; 79:479-484.

3. American Academy of Pediatrics. Children in out-of-home child care. In: Pickering LK, Baker CJ, Kimberlin DW, Long SS, eds. Red Book: 2009 Report of the Committee on Infectious Diseases. 28th ed. Elk Grove Village, IL: American Academy of Pediatrics; 2009:124-140.

4. Lyman WH, Walsh JF, Kotch JB, Weber DJ, Gunn E, Vinjé J. Prospective study of etiologic agents of acute gastroenteritis outbreaks in child care centers. J Pediatr 2009;154(2):253-257.

5. Shope TR, Aronson S. Improving the health and safety of children in nonparental early education and child care. Pediatr Rev 2005;26(3):86-95.

6. Clements DA, Moreira SP, Coplan PM, Bland CL, Walter EB. Postlicensure study of varicella vaccine effectiveness in a day-care setting. Pediatr Infect Dis J 1999; 18:1047-1050.

7. Hurwitz ES, Gunn WJ, Pinsky PF, Schonberger LB. Risk of respiratory illness associated with day-care attendance: a nationwide study. Pediatrics 1991;87(1):62-69.

8. Rosenfeldt V, Vesikari T, Pang X-L, Zeng S-Q, Tvede M, Paerregaard A. Viral etiology and incidence of acute gastroenteritis in young children attending day-care centers. Pediatr Infect Dis J 2005; 24:962-965.

9. American Academy of Pediatrics, American Public Health Association, National Resource Center for Health and Safety in Child Care. Caring for Our Children: National Health and Safety Performance Standards; Guidelines for Out-of-Home Child Care Programs. 2nd ed Elk Grove Village, IL: American Academy of Pediatrics; and Washington, DC: American Public Health Association, 2002.

10. Ray R, Gornick JC, Schmitt J. Parental leave policies in 21 countries: assessing generosity and gender equality. http://www.lisproject.org/ publications/parentwork/parentleavereport.pdf. Washington DC: Center for Economic and Policy Research. September 2008. Revised June 2009. Accessed January 10, 2010. 